\title{
Transmission of Microdochium albescens from seeds to seedlings in the pre-germinated cultivation system of irrigated rice
}

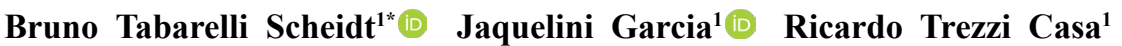 \\ Cileide Maria Medeiros Coelho ${ }^{1}$ Amauri Bogo ${ }^{1}$ Juliano Berghetti ${ }^{1}$
}

${ }^{1}$ Programa de Pós-graduação em Produção Vegetal (PPGPV), Universidade do Estado de Santa Catarina (UDESC), 88520-000, Lages, SC, Brasil. E-mail: brunotabarelli.s@hotmail.com. "Corresponding author.

ABSTRACT: The fungus Microdochium albescens is one of the main pathogens associated with irrigated rice seeds in southern Brazil. The objective of the present study was to quantify the transmission of $M$. albescens from naturally infected seeds to the crown, coleoptile, and first true leaf of the seedlings of six cultivars growing in pre-germinated cultivation system of irrigated rice. Seeding was carried out on a watersaturated substrate, using four untreated seed lots for each of the six cultivars. At 14 days after sowing, the crown, coleoptile, and first true leaf of the seedlings were carefully highlighted, and the samples were disinfected and plated onto potato-sucrose-agar culture medium. M. albescens was transmitted asymptomatically to crown, coleoptile, and first true leaf, at rates of 39.3\%, 25.8\%, and 5.4\%, respectively (these values represent the average incidence of the six cultivars). This is the first report that proves that M. albescens is transmitted from infected seeds to irrigated rice seedlings in a pre-germinated seed system.

Key words: Oryza sativa, Gerlachia oryzae, infected seed, transmission rate.

Transmissão de Microdochium albescens de sementes para plântulas de arroz irrigado no sistema de cultivo pré-germinado

\begin{abstract}
RESUMO: O fungo Microdochium albescens é um dos principais patógenos associados às sementes de arroz irrigado no sul do Brasil. O objetivo do presente estudo foi quantificar a transmissão de M. albescens de sementes naturalmente infectadas para a coroa, coleóptilo e primeira folha verdadeira das plântulas de seis cultivares semeadas em sistema de cultivo pré-germinado de arroz irrigado. A semeadura foi realizada em substrato saturado com água, utilizando quatro lotes de sementes não tratadas para cada uma das seis cultivares. Aos 14 dias após a semeadura, a coroa, o coleóptilo e a primeira folha verdadeira das plântulas foram cuidadosamente dissecados, desinfestados e plaqueados em meio de cultura batata-sacarose-ágar. M. abescens foi transmitido de forma assintomática para coroa, coleóptilo e primeira folha verdadeira, nas taxas de 39,3\%, 25,8\% e 5,4\%, respectivamente (estes valores representam a incidência média das seis cultivares). Este é o primeiro relato de M. albescens transmitido de sementes infectadas para plântulas de arroz irrigado em sistema de semente pré-germinada. Palavras-chave: Oryza sativa, Gerlachia oryzae, semente infectada, taxa de transmissão.
\end{abstract}

Rice (Oryza sativa L.) is the second most cultivated cereal crop in the world. Brazil grows approximately 2 million hectares and a produces 12 million tons. Irrigated rice cultivation is predominant in the states of Santa Catarina and Rio Grande do Sul. The climatic conditions favoring rice cultivation in southern Brazil also favor the occurrence of several diseases. Rice blast, caused by the fungus Pyricularia oryzae Cav.), is emphasized as the main disease. Other diseases that have occurred frequently in recent years included brown spot (Bipolaris oryzae Breda de Haan), narrow brown leaf spot (Cercospora oryzae Miyake), and leaf scald (Microdochium albescens Thüm (Syn. Microdochium oryzae Hashioka \& Yokogi; Gerlachia oryzae Hashioka \& Yokogi)) (SOSBAI, 2016).

Infected seeds are considered to be a source of primary inoculum, and transmission of the fungus in rain fed crops occurs through infected seeds that further causes discoloration on infected seedlings (FILIPPI et al., 2005; GUTIÉRREZ, 2008). Leaf scald reduces the number, weight and physiological quality of seeds (MOURA et al., 2014), causing up to $30 \%$ reduction in yield (THOMAS, 1984). In seed pathology test performed in the Plant Pathology Laboratory of Universidade do Estado de Santa 
Catarina, irrigated rice seeds collected during the 2015/16, 2016/17 and 2017/18 harvests in the state of Santa Catarina, revealed $100 \%$ of prevalence of the $M$. albescens, with mean incidence above $50 \%$ (unpublished data). According to the Technical Department of the Cooperative Cravil, which is responsible for the increased production of irrigated rice seeds in the state of Santa Catarina, the occurrence of leaf scald increased considerably in rice fields. However, information on the epidemiology of this disease in southern Brazil and particularly, on the importance of infected seed of the introduction of the pathogen into irrigated rice crops using the pre-germinated seed system is lacking. The present study aimed to quantify the transmission of $M$. albescens from naturally infected seeds to the crown, coleoptile, and first true leaf of the seedlings of six cultivars growing in pre-germinated cultivation system of irrigated rice.

Seeds of the rice cultivars SCSBRS Tio Taka, Epagri 109, SCS116 Satoru, SCS118 Marquês, SCS121 CL and SCS122 Miura were collected in the Alto Vale do Itajaí region from the 2016/17 harvest and supplied by the Cooperative Cravil. The seed phatology test was performed on several seed lots for each cultivar to detect and quantify the incidence of the fungus and thereby identifying four seed lots per cultivar (two lots above and two lots below $50 \%$ incidence) with natural $M$. albescens infection, totaling 24 lots of untreated naturally infected seeds. The seeding was carried out in a greenhouse in a 3:1 mixture of soil and coarse sand without fungus. The mixture was filled in 48 plastic trays $(54.5 \mathrm{~cm}$ long $\times 37 \mathrm{~cm}$ wide $\times 9 \mathrm{~cm}$ high) and conditioned in a flooded environment for 30 days before sowing. Before sowing, seeds were immersed in distilled water for $36 \mathrm{~h}$ and; subsequently, removed and transferred onto moistened germitest paper in the dark for another $36 \mathrm{~h}$ to induce the germination. After this duration, the seeds were at the "needle point;" this is the ideal phenological stage for sowing in the pre-germinated seed system (SOSBAI, 2016). The pre-germinated seeds of all the seed lots were seeded in a $2-\mathrm{cm}$ water slide, with 50 seeds per tray, with four replicate trays of each of the 24 treatments arranged in a completely randomized design. The temperature of the greenhouse during the experiment was maintained at $26 \pm 2{ }^{\circ} \mathrm{C}$. At 14 days after sowing, 25 seedlings were sampled at random from each of four replicate trays for each of the 24 [seed lot $\times$ cultivar] combinations. The seedlings were removed from the tray, washed in running water to remove the substrate and sent to laboratory. The crown, coleoptile and first true leaf were removed from each seedling using a sterilized scalpel, disinfected in sodium hypochlorite solution (1\%) for two minutes, and then rinsed in sterile distilled water and dried on germitest paper in a laminar air flow chamber. Plant organs were plated onto Petri dishes ( $9.0 \mathrm{~cm}$ diameter) of potato-sucroseagar (PSA) culture medium containing antibiotic (streptomycin sulfate at a working concentration of $\left.0.36 \mathrm{~g} \mathrm{DAL}^{-1}\right)$. The plates were incubated for 7 days in a growth chamber at a temperature of $25 \pm 2{ }^{\circ} \mathrm{C}$ and a 12-h light/12-h dark cycle. The identification of the fungus $M$. albescens was confirmed under a binocular microscope and optical microscope.

Transmission of the fungus from the seed to each plant organ was expressed as percentage incidence in the organ relative to the incidence in the original seed lot. Data were approximated to normality and analyzed using ANOVA; mean values from the different treatments were compared for significance using the Tukey test $(\mathrm{P}<0.05)$, using $\mathrm{R}$ software, version 3.4.1 (R Core Team, 2017). The mean incidence of the $M$. albescens fungus in the six irrigated rice cultivars was $48 \%$ (Table 1), ranging from $32.7 \%$ in SCS122 Miura to $57.5 \%$ in SCS116 Satoru. Regardless of the cultivar, the transmission rate was highest for the crown and lowest in the first leaf. A mean transmission rate of $39.3 \%(0.393: 1)$ for the crown, $25.8 \%(0.258: 1)$ for the coleoptile and $5.4 \%$ (0.054:1) for the first true leaf was observed across all seed lots and cultivars. The range of transmission rates for each organ varied from $30 \%$ to $50 \%$ in the crown, from $18.7 \%$ to $50 \%$ in the coleoptile and from $0 \%$ to $19.2 \%$ in the first true leaf, according to the cultivar and the seed lot (Table 1). The lowest transmission rate to the crown $(36.1 \%)$ was observed in the cultivar SCS 122 Miura, whereas the highest rate in this same organ was $42.4 \%$ in the cultivar Epagri 109. For the coleoptile, the lowest rate occurred in SCSBRS Tio Taka (19.7\%) whereas SCS121 CL exhibited the highest rate $(30.6 \%)$. The cultivars SCSBRS Tio Taka and SCS118 Marquês showed no transmission of the fungus to the first leaf, whereas the highest average value (10.7\%) was observed in cultivar Epagri 109 for the same organ (Table 1). When analyzing the seedlings, no symptoms, such as discoloration, darkening, chlorosis, or the presence of necrotic lesions, were observed in any cultivar regardless of the organ investigated. In this study, the fungus was transmitted asymptomatically for at least 14 days after sowing.

The transmission rate of $M$. albescens to the crown was not related to its incidence in seeds, that is, there may be a higher batch transmission rate 
Table 1 - Average incidence of Microdochium albescens and seed fungus transmission rate for seedlings of irrigated rice cultivars. Lages, SC, 2018.

\begin{tabular}{|c|c|c|c|c|}
\hline \multirow[t]{2}{*}{ Cultivar } & \multirow[t]{2}{*}{ Incidence on seed $(\%)$} & \multicolumn{3}{|c|}{------------------------------Transmission rate $(\%)^{1}---------------------$} \\
\hline & & Crown & Coleoptile & First leaf \\
\hline SCS BRS Tio Taka & 57.3 & $38.1 \mathrm{a}$ & $19.7 \mathrm{~b}$ & $0.0 \mathrm{c}$ \\
\hline EPAGRI 109 & 44.5 & $42.4 \mathrm{a}$ & $29.1 \mathrm{~b}$ & $10.7 \mathrm{c}$ \\
\hline SCS 116 Satoru & 57.5 & $37.6 \mathrm{a}$ & $24.4 \mathrm{~b}$ & $5.2 \mathrm{c}$ \\
\hline SCS 118 Marquês & 56.3 & $40.2 \mathrm{a}$ & $26.3 \mathrm{~b}$ & $0.0 \mathrm{c}$ \\
\hline SCS $121 \mathrm{CL}$ & 42.0 & $41.3 \mathrm{a}$ & $30.6 \mathrm{~b}$ & $9.3 \mathrm{c}$ \\
\hline SCS 122 Miura & 32.7 & $36.1 \mathrm{a}$ & $25.0 \mathrm{~b}$ & $7.0 \mathrm{c}$ \\
\hline Average overall & 48.4 & $39.3 \mathrm{a}$ & $25.8 \mathrm{~b}$ & $5.4 \mathrm{c}$ \\
\hline
\end{tabular}

${ }^{1}$ Avalued in seedlings at 14 days after sowing; Rate calculated based on fungus incidence in seed and incidence of fungus detection in plant structure. Means followed by the same letter in line do not differ statistically from each other by the Tukey test (P $\leq 0.05)$.

of lower incidence of the fungus. In the present study, transmission rates to the crown in all six cultivars remained similar, approximately $40 \%$, regardless of the disease incidence level in the seeds. Conversely, in a study by GUTIÉRREZ (2008), M. oryzae was detected 30 days after sowing (rain fed system), with a transmission rate of $2.2 \%$ to the coleoptile from seeds with $55 \%$ incidence. Although, transmission of the fungus from seeds to seedlings can be affected by several factors, the location (embryo, endosperm, lemma, or palea) of the fungus is considered to be the most important factor in the transmission process. In a study by SINGH \& SEN GUPTA (1981), $M$. oryzae was reported only on non-disinfested seeds, indicating that the fungus was restricted to the outside of the seed. However, the fungus can also be located internally within the seed (MAUDE, 1996); in the current study, for example, seeds which had been surface sterilized retained $M$. oryzae inoculum. Fragmentation of the seeds showed the highest frequency of the fungus in the endosperm, but it could also be detected in the embryo, palea, basal glumes, and lemma (MANANDHAR, 1999). The present study concluded that the infected seed can be a source of inoculum for the occurrence of leaf scald in the fields of irrigated rice using the pre-germinated seed system in the state of Santa Catarina.

\section{ACKNOWLEDGEMENTS}

The reserach was financed in part by the Coordenação de Aperfeiçoamento de Pessoal de Nível Superior (CAPES), Brasil, Finance code 001. JB has scholarship from Fundação de Amparo à Pesquisa e Inovação do Estado de
Santa Catarina (FAPESC). JG has scholarship from Fundo de Apoio à Manutenção e ao Desenvolvimento da Educação Superior (FUMDES).

\section{DECLARATION OF CONFLICT OF} INTERESTS

The authors declare no conflict of interest. The founding sponsors had no role in the design of the study; in the collection, analyses, or interpretation of data; in the writing of the manuscript, and in the decision to publish the results.

\section{AUTHORS' CONTRIBUTIONS}

BTS, RTC and AB conceived and designed experiments. BTS, JB and JG performed the experiments, BTS carried out the lab analyses. CMMC e JG performed statistical analyses of experimental data. BTS, JG and JB prepared the draft of the manuscript. All authors critically revised the manuscript and approved of the final version.

\section{REFERENCES}

FILIPPI, M. C.; PRABHU, A. S.; SILVA, G. B. Escaldadura do arroz e seu controle. Circular técnica 72. Santo Antônio de Goiás. Embrapa Arroz e Feijão. p.4, 2005.

GUTIÉRREZ, S. A. et al. Detection and transmission of Microdochium oryzae from rice seed in Argentina. Australian Plant Disease. v.3, p.75-77, 2008. Available from: <https:// link.springer.com/content/pdf/10.1007\%2FBF03211246.pdf>. Accessed: Jul. 20, 2018. doi: 10.1071/DN08030.

MANANDHAR, J. B. Isolation of Microdochium oryzae and Pinatubo oryzae from rice seeds and their survival on stored seeds. European Journal of Plant Pathology, v.105, p.139145, 1999. Available from: <https://link.springer.com/content/ pdf/10.1023/A:1008765523465.pdf >. Accessed: Aug. 02, 2018. doi: $10.1023 / \mathrm{A}: 100876552$ 
MAUDE, R. B. Seedborne diseases and their control: principle and practice. CAB International: Wallingford, UK p.280, 1996.

MOURA, A. B. et al. Biocontrol and seed transmission of Bipolaris oryzae and Gerlachia oryzae to rice seedlings. Journal of Seed Science, v.36, p.407-412, 2014. Available from: <http://dx.doi. org/10.1590/2317-1545v36n41009>. Accessed: Jun. 12, 2018. doi: 10.1590/2317-1545v36n41009.

SINGH, A.S.; SEN GUPTA, P.K. Transmission of Rhynchosporium oryzae Hashioka and Yokogi by seed. International Rice Research Notes v.6, p.11, 1981.
SOSBAI. Arroz irrigado: recomendações técnicas da pesquisa para o Sul do Brasil / Sociedade Sul-Brasileira de Arroz Irrigado; XXXI Reunião Técnica da Cultura do Arroz Irrigado. Bento Gonçalves, RS, p.200, 2016. Online. Available from: <http:// www.sosbai.com.br/docs/Boletim_RT_2016.pdf>. Accessed: Aug. 22, 2018.

THOMAS, M. D. Dry-season survival of Rhynchosporium oryzae in rice leaves and stored seeds. Mycologia, v.76, p.1111-1113, 1984. Available from: <https://www.jstor. org/stable/3793027>. Accessed: Sep. 23, 2018. doi: $10.2307 / 3793027$. 